\title{
SH6 - Dinámica de uso de suelo y su relación con los patrones de escorrentía superficial, Subcuenca III Managua. Nicaragua
}

\author{
Ingrid E. Úbeda T. \\ Departamento de Geografía \\ Facultad de Humanidades y Ciencias Jurídicas \\ Universidad Nacional Autónoma de Nicaragua (UNAN-Managua)
}

\section{Resumen}

$\mathrm{E}$

ste artículo muestra algunos resultados del presente tema de investigación. Se planteara los aspectos prácticos

para una modelación estadístico-espacial de la dinámica cambio de usos del suelo ocurrido en la Subcuenca III, de la Cuenca sur del lago de Managua, Nicaragua. Comprende un análisis retrospectivo de 19 años y una simulación de uso de suelo. Para ello se emplearon imágenes multiespectrales de Landsat (7-8) de cuatros fechas: 1997, 2003, 2010, 2016 que se interpretaron siguiendo el método de clasificación interdependiente y el algoritmo multiresolution segmentation a una escala de $100 \mathrm{~m}$. La simulación de los usos de suelo se determinó mediante cadenas de Markov y el modelo lineal generalizado (GML) desarrollado con el software libre de R. Las variables independientes consideradas fueron distancia a: vías, ciudad, red de drenaje, modelo de elevación digital y la pendiente en grado. De acuerdo a los cambios de usos de suelo que se han producido, se calculará la escorrentía superficial mediante el método de Número de Curva (NC) desarrollado por el servicio de conservación de suelos del departamento de Agricultura de los Estados Unidos y es uno de los métodos más extendido y utilizado

Palabras clave: Usos de suelo, simulación, estadístico, espacial, escorrentía superficial.

\begin{abstract}
$\mathrm{T}$ his article shows some results of this research topic. It poses practical aspects for statistical and spatial modeling dynamic change of land use occurred in subwatershed III, the southern basin of Lake Managua, Nicaragua. It comprises a retrospective analysis of 19 years and a simulation of land use. To do Landsat multispectral images were used (7-8), of four dates: 1997, 2003, 2010, 2016. That performed following the method of classification interdependent interdependent and multiresolution segmentation algorithm on a scale of $100 \mathrm{~m}$. to simulate soil use is determined Markov chains and generalized linear model (GLM). developed with free software R. The independent variables were distance: roads, city drainage network, digital elevation model and slope in degree. According to land use changes that have occurred surface runoff is calculated by Curve Number method (NC), developed by the Soil Conservation Service of the United States Department of Agriculture and it is one of the most widespread and used methods.
\end{abstract}

